\title{
THE SYSTEM OF FORMATION AND EVALUATION OF THE INFORMATION OF CASH FLOWS
}

\author{
Jonas Mackevičius ${ }^{1}$, Kastytis Senkus² \\ 1,2 Vilnius University, Saulètekio al. 9, LT-10222 Vilnius, Lithuania \\ Phone: ${ }^{1}+3705236$ 6153; ${ }^{2}+37061210824$ \\ E-mail: ${ }^{1}$ jonas.mackevicius@ef.vu.lt; ${ }^{2}$ kastytis.senkus@ef.vu.lt \\ Received 3 July 2006; accepted 10 October 2006
}

\begin{abstract}
A very urgent problem of formation of cash flows in conditions of the competitive market is considered in the present article. Cash flows are defined as the inflows and outflows of cash and cash equivalents, created within a certain period of time out of the operating, financial, investment and extraordinary activities of the company. Examples of cash flows out of the operating, financial and investment activities of the company are adduced.

The system of formation and evaluation of the information about cash flows is created. Its principal elements are as follows: cash flow accounting, classification of cash flows, issuing of the cash flow statement, control and analysis of cash flows, cash flow forecasting.

The methods of analysis of cash flows are created, i.e. the horizontal analysis of the cash flow statement; the vertical analysis of the cash flow statement; the analysis of financial ratios of the cash flow statement; preparation of the cash flow forecast.

Practical application of the system of formation and evaluation of the information about cash flows would help the company managers to take various management decisions on evaluation of the company's financial condition and its activity results better, quicker and more precisely.
\end{abstract}

Keywords: cash flows, accounting, control, analysis of cash flows.

\section{Introduction}

Each operating company seeks for gaining a larger profit and for continuity of its activity. However, even the profitable company may occur at the edge of bankruptcy, if it experiences a constant deficit of money. The company, which is short of money, is unable to implement its liabilities. Thus, seeking for assurance of the company's profitableness and continuity of its activity, it is very important to manifest a clever approach towards management of cash flows. The cash flows, generated by the company, and the information, related with them, are useful for all the users of financial information. The data about cash flows are especially important for shareholders, managers, investors and creditors. The shareholders need the information about cash flows for evaluation of the possibilities of the company development and its solvency condition, for evaluation of the company's ability to cover its liabilities and to fulfill its other financial liabilities. The investors and creditors need to know, if the positive cash flows will enter the company, if the company will pay out the dividends, if the com- pany will return the loans and interests and, in general, if the company managers will be able to manage cash flows efficiently.

The appropriate formation of the information about cash flows and its evaluation are very important factors for the company's successful activity. Formation and evaluation of the information about cash flows implies accounting, control, analysis and forecasting of the information about the company's cash flows. This information is especially valuable for the top management of the company while taking the management decisions and while forecasting the activity perspectives. The proper management of cash flows helps to reveal timely the shortcomings of various spheres of the company's activity and of its subsidiaries' activity, to foresee the measures of their elimination and improvement of effectiveness of its activity. However, the problems of formation and evaluation of the information about cash flows have not been sufficiently investigated yet.

It should be stressed that importance of proper formation and evaluation of the information about cash 
flows has especially increased within the conditions of the competitive market of the European Union. The companies, which seek to be competitive and to strengthen their position both at the local and foreign markets, should devote the paramount attention towards formation of the information about cash flows, its alteration and impact upon the company's financial condition. It was revealed in the course of the investigation that there is no detailed and universal system of formation and evaluation of the information about cash flows. Most authors analyze only separate elements of this system, usually the methods of issuing of cash flow statements. Thus, the company managers do not receive the necessary information about cash flows, enabling them to take the decisions on the company management.

\section{Classification of cash flows}

None of the companies, institutions or organizations can carry out its activity without the money. The money is an axis, around which each person's personal and economic life rotates. It is the most important motive force of all business deals. At different periods of time various objects used to serve as the money for different countries of the world. This was predetermined by economic, historic, social, political and cultural conditions of the country. Within change of the times, the money itself and its functions have changed as well, however the money always had and still has one, the most important peculiarity, i.e. it helps a person to save and accumulate his/hers earned property. If a person has the money, any exchange and payment can be effected. The money is everything, which acts as an intermediary, as the value measurement, as means of future payments or as liquid accumulation means (Mayer et al 1995: 20); it is assets, which are often used as means of exchange (Pass et al 1997: 371). The money is the most mobile shortterm assets of the company; thus, solvency, profitability and continuity of the company's activity depend upon the amount of money and its turnover. Seeking for effective, profitable and constant activity, the company must have sufficient amounts of money and be capable of managing them in the right way so as to be able to keep a continuous coverage of indebtedness and other current dues. The company's money must be managed in such a way, so that it could help to earn the income and create new assets in the most efficient way.

The money should not be identified with cash flows. Cash flows are the inflows and outflows of cash and cash equivalents as well as dues within a certain period of time (International Financial Reporting Standards (IFRS) 2004: 635; National Accounting Standards (NAS) 2004: 64). The inflow is the increase of cash and cash equivalents in the cash desk of the company or at its bank accounts. This increase of cash or cash equivalents is stipulated by various reasons, i.e. the customers transfer the cash for the purchased goods or/and for the services, rendered to them; the company gets a loan; there is a certain increase of money in the cash-desk through alteration of the rates of exchange of the currency, etc. Outflows of cash

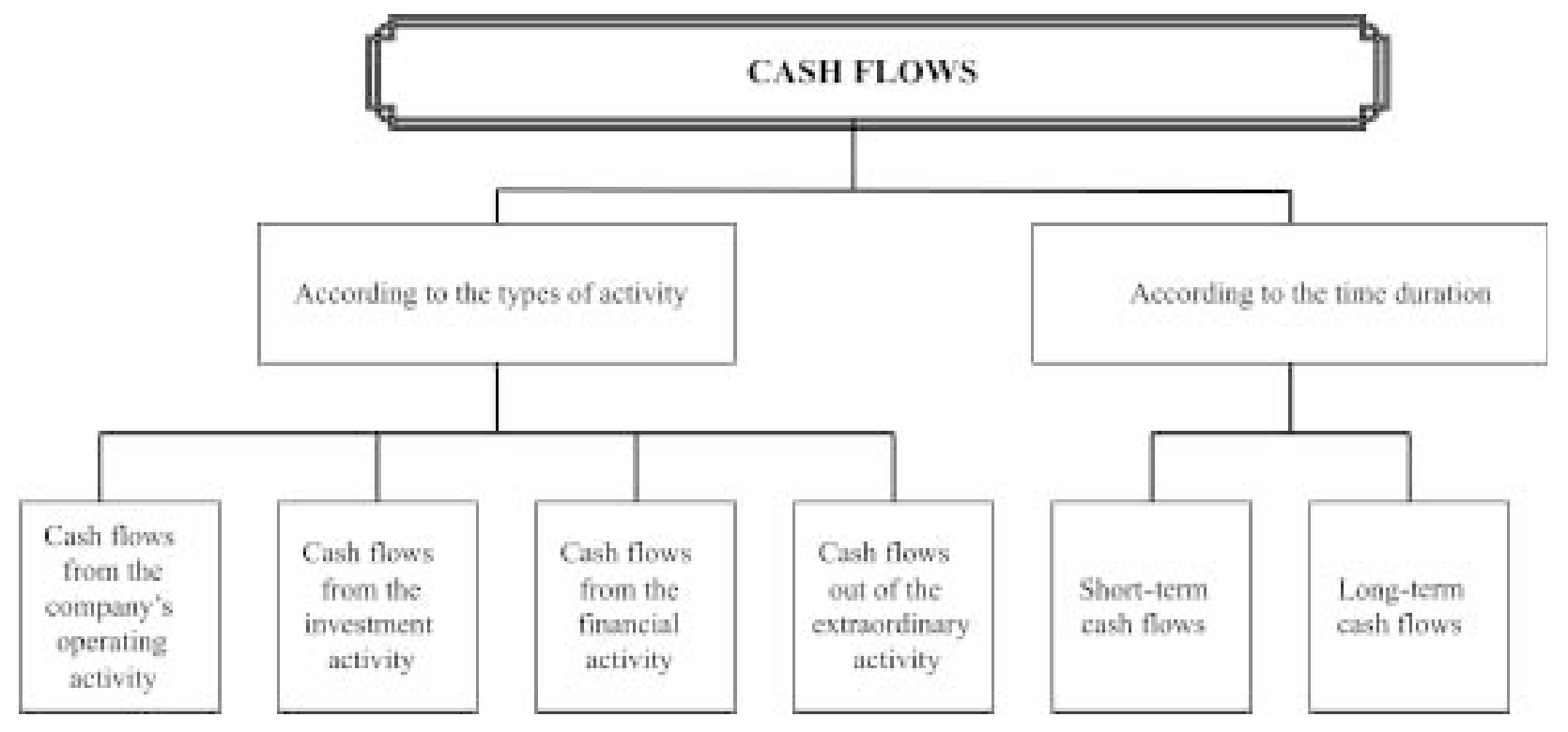

Fig 1. Classification of cash flows 
are the decrease of money in the cash desk of the company or at its bank account. There are different dues, i.e. the dues to be paid to the suppliers for raw materials and materials, for production and repair jobs, for payment of the remuneration, dividends, etc.

The company's solvency, profitability and continuity of its activity depend upon the company's cash flows. Seeking to provide the users with a more specified information about the cash flows, it's worth to stream and analyze the cash flows according to the following most important criteria, i.e. 1) according to the types of activity and 2) according to the time duration (Fig 1).

Classification of cash flows according to the types of activity provides the information, which offers to the users the possibility to evaluate the influence of such activity upon the company's financial condition and the amount of cash and cash equivalents as well as to evaluate the relations in between the types of activity.

The investigation, which was carried out in the Lithuanian companies, which are involved in the processing industry, proves that the largest cash flows are earned out of the operating activity (approximately $60 \%$ ) and the smallest cash flows - out of the financial activity (approximately $15 \%$ ) (Fig 2).

Cash flows inflows and outflows are very different. Basic cash flows inflows and outflows from company's operating, investment and financial activities are displayed in Fig 3.

The cash flows from operating activities are the cash flows, related with the operating activity of the company (the production, trade or service rendering activity), except the financial and investment activities.
The cash flows of the company's operating activity serve as the principal rate, which helps to ascertain to which extent the company's typical and other activities, without the external sources of financing, provides the possibility to develop the company's production capacity, to return the debts, to pay out the dividends and to invest the funds (IFRS 2004: 635). The cash outflows from the operating activity are received out of the economic operations and events, which serve as the grounds for fixing the net profit or the loss. The results of the investigation, which has been carried out, prove that the following inflows out of the operating activity make the largest comparative part, i.e. the inflows after having sold the goods or after having rendered the services (approximately $50 \%$ ); the inflows, received in the shape of the customers' advanced payment for the goods (approximately $10 \%$ ) and the inflows, received after having regained the trade debts (approximately $25 \%$ ). The outflows, meant for suppliers of raw materials, goods and services $(25 \%)$, the outflows, meant for the company employees (40\%), and the paid taxes (25\%) are the usually repeated outflows from the operating activities of the company.

The cash flows from investment activities are the cash flows, related with acquisition and sale of the long-term assets (tangible and intangible), with acquisition and sale of securities of the other companies, with granting of the loans to the other companies (i.e. their investment as a result of borrowing the loan for interests) and with return of the loan in future. The cash flows, related with the investment activity of the company, are reflected separately, seeking to know the current expenditures of the company so as to receive the inflows in future.
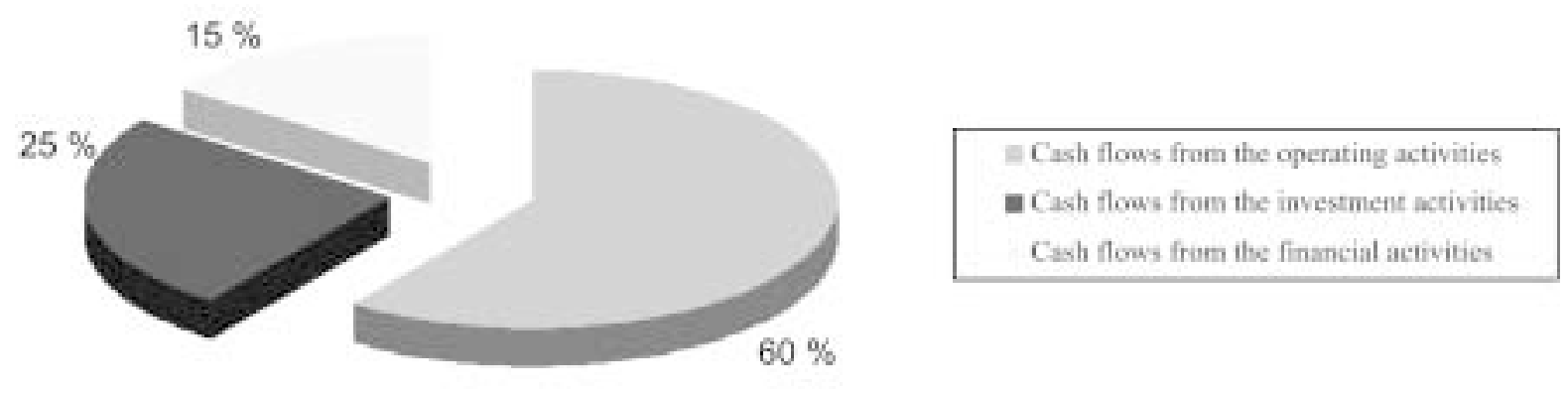

Fig 2. The comparative weight of the companies' cash flows in the Lithuanian companies, which are involved in the processing industry, in the year 2004 


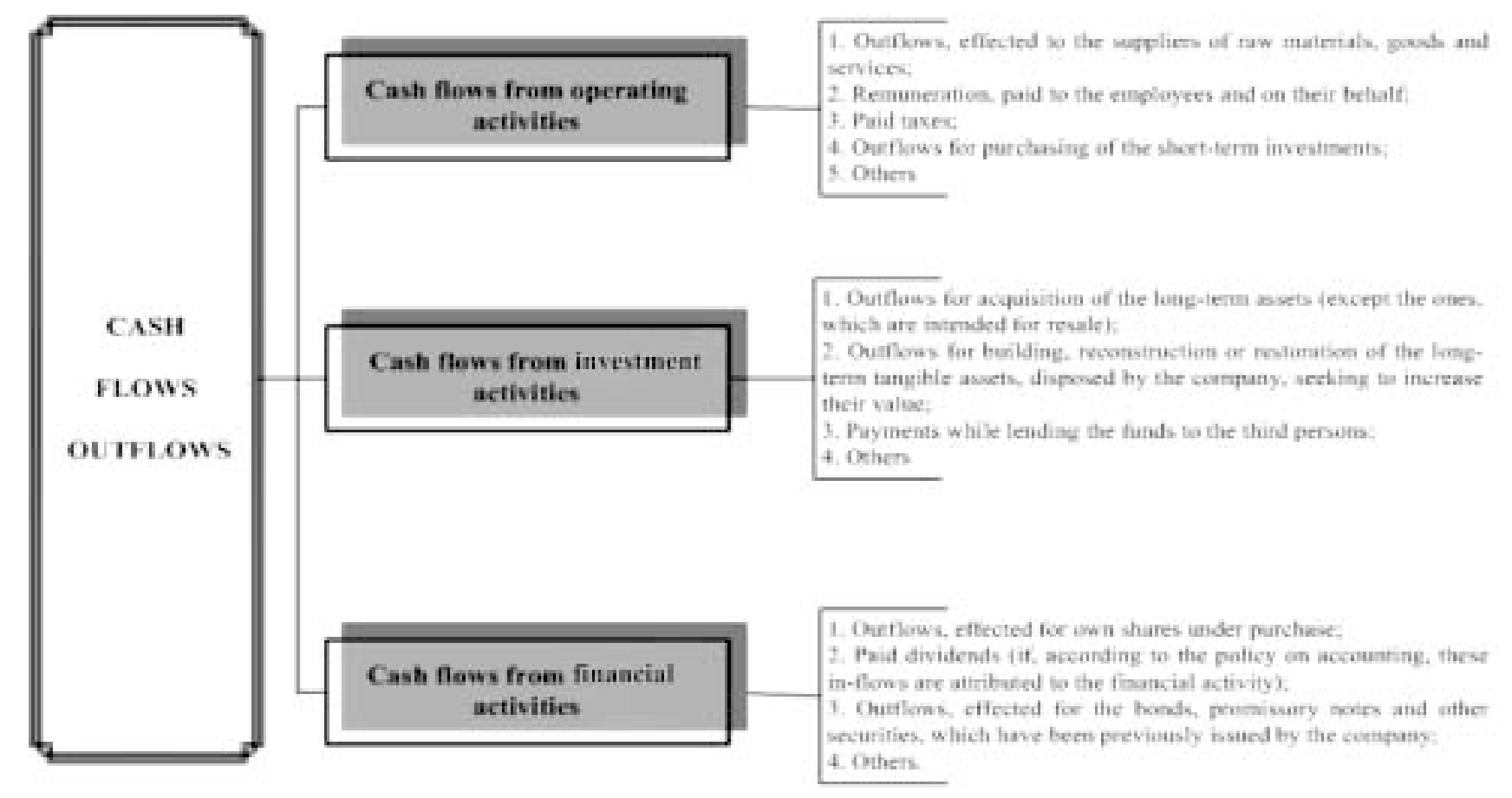

Fig 3. Cash flows outflows

The results of the investigation, which has been carried out, prove that the following inflows out of the investment activity of the company make the largest part, i.e. the inflows, received as a result of passing of the long-term assets through (approximately $43 \%$ ) and the inflows, received as a result of passing of the other companies' securities through, acquired not for resale (approximately $29 \%$ ). The most frequent and the largest outflows from the company's investment activities are as follows: the outflows for acquisition of the long-term assets (approximately $39 \%$ ) and the outflows for acquisition of securities (approximately $38 \%)$.

The cash flows from financial activities reflect the investments of the current and future owners of the company and the benefit, gained owing to them. The cash flows out of this activity provide the possibility to ascertain the company's efforts in employment of the external sources of financing as well as alteration of the monetary relationship in between the company and the third persons. According to the 7-th International accounting standard, it's important to reveal the cash flows out of the financial activity because it is useful for forecasting claims of the capital suppliers of the company towards the cash flows within the future periods (IFRS 2004: 638).

The inflows out of borrowing make the largest part of the inflows out of the company's financial activity (approximately $57 \%$ ), whereas the loan return makes the most important payments out of the company's financial activity (approximately $43 \%$ ), the payments for leasing make approximately $18 \%$ and the payments for acquisition of securities make approximately $9 \%$.

According to the time duration, cash flows can be streamed into the short-term and long-term cash flows. The short-term cash flows usually depend upon the cycle of the company's activity. The duration of the cycle of the company's activity can be defined by a) the period of the stock circulation, i.e. an average number of days, during which the product is manufactured and sold; b) the period of circulation of receivables, i.e. an average number of days, during which the buyers' indebtedness for the goods, purchased on the consignment grounds, is covered.

Formation of the information about the long-term cash flows implies ascertainment of the company's external demand for financing and the investment decisions. In this case, the inflows and the outflows, related with investment and financing of the company, should be managed. Ascertainment of the demand for the external financing is grounded by preparation of the cash flow budgets and forecasts. While analyzing the long-term cash flows, it is necessary to evaluate not only the volume of the product sales, the products' prime-cost and various other costs, but also the buyers' delayed accounting, the creditors' delayed return of the loans, etc. Actually, the longer the period is, the larger the risk is. Thus, it is necessary to investigate the factors, which influence the long-term cash flows (Fig 4). 


\section{FACTORS, INFLENCING THE LONG-TERM CASH FLOWS}

S.t.is

BEMTNEATION
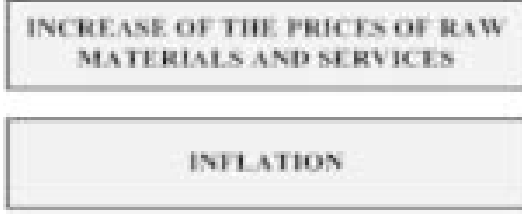

BUVES' SOLVENCY

CONPETITION

INTHEST

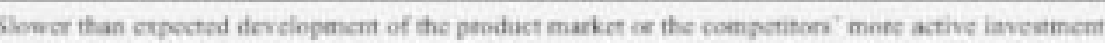

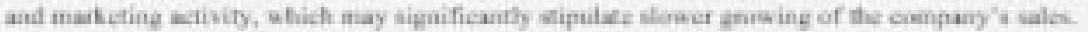

Faser thas exposted incruse of the Lithuaian dwcllers" incoese, which nay fuese the company to incrase the remanenatius. Simultanesosly, aves, related with the remameratice, increase.

Fater then expected increase of the fiel and enern priess as well as increase of thes consumption by the company, which may sipulate faster iscrease of the company's eosh for fuef and energy

Foler thas expected inflative, wich thay dipulate faster ificrame of the peices fur the sen km,

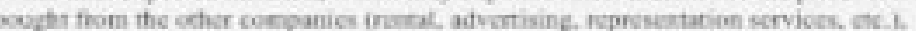

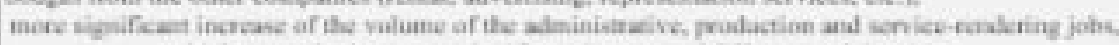
which nas stiphilec mere sienificant inctease of differamt activity costs.

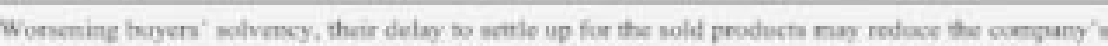
expected inflows, wich may stipulate the lout bonowing

Mose autive comperition mpanting the compony's peodoct at the markir, which may stipulate fasta

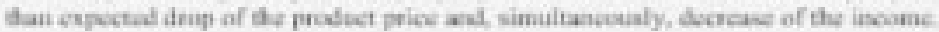

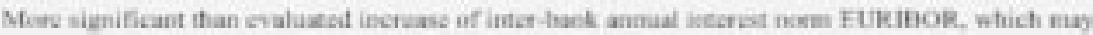
stipulate larger inierests to be puid by the company to the conda iustitaions

Fig 4. The factors, which influence the long-term cash flows

Within the conditions of the current competitive market, it is important to manage scrupulously the information about cash flows, which could be used by the internal and external information users for taking various decisions. The information about cash flows, like any other economic information, should be understandable, suitable, reliable, comparable and timely submitted. The accumulated information about cash flows should be appropriately evaluated and used. The system of formation and evaluation of the information about cash flows is submitted in Fig 5.

The primary information is accumulated in the appropriate registers of analytical and synthetic accounting. This information can be streamed according to various indications (for example, according to the types of the company's activity, periods, objectives, purpose, etc.), which would assist the users to understand it better and to use it for gaining various objectives. The accumulated information about cash flows should be used for taking various decisions regarding management. The money should be managed in such a way, so that not only all liabilities are fulfilled, but the funds, available in the company, are efficiently used, i.e. "the money creates the money".

\section{Accounting and control of cash flows}

For the first time in the world the term "Cash flow statement" was mentioned in the year 1987 in the USA standard No 95, issued by the Board of Standards on Accounting "Cash Flow Statements" (earlier this statement used to be called the fund statement, the cash flow statement, the statement of the fund sources and their application, the statement of alteration of the financial condition, etc.). The term "Cash flow statement" was mentioned in Lithuania for the first time in Resolution No 804, adopted by the Government of the Republic of Lithuania on October 27, 1993, "Regarding the annual financial accountability of the companies, entitled to the juridical person's rights". The statement of alteration of the financial condition (cash flows) was approved by the above-specified Resolution. Several main reasons can be singled out, which caused delay of introduction of the cash flow statement, i.e.:

1. Confidentiality - The companies never wish to announce the detailed information about the condition of their funds and the sources of their receipt and employment.

2. Resistance to novelties - The cash flow statement is the most complicated among the existing statements. Accountants were not interested in spending the time on issuing the new statements and on going deeper into the frailties of their issuing.

3. Issuing of the statement as per the money principle - The experts of the book-keeping accounting used to stress constantly the drawbacks of accounting, 


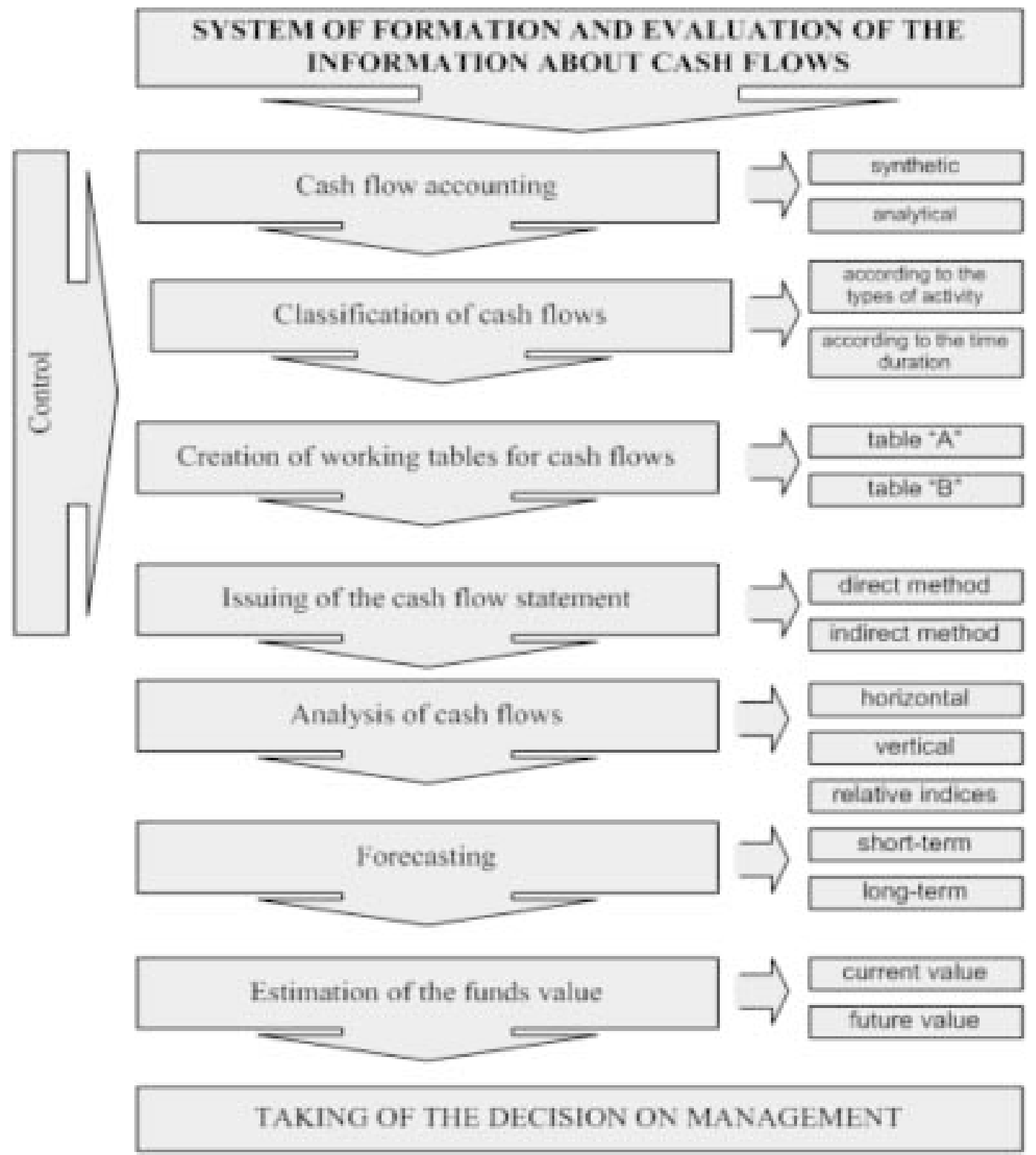

Fig 5. The system of formation and evaluation of the information about cash flows

managed according to the principle of money accounting, and used to raise importance of accounting, managed according to the principle of accumulation.

The most important reasons, which predetermined the necessity of introduction of the cash flow statement, are: 1) necessity of the information for investors and creditors - while investing or lending the funds to the company, the investor or the creditor should know how, when and from whom the funds will be returned. The cash flow statement reflects all this information; 2) necessity of availability of the information about the company's liquid assets and its financial condition - with the help of the statement, after having carried out the analysis, the information user can judge about the company's liquid assets, its financial condition and can come to the conclusion, if it is acceptable to him/her; 3) the cash flow statement, unlike the other financial statements, which are issued according to the principle of accumulation, reflect the inflows and outflows within a certain period of time as per the types of activity. This information is extremely valuable while taking the decisions on management; 4) the information from the cash flow statement helps to evaluate the value of the funds for the current moment and for the future; 5) importance of the information about cash flows for the state institutions, which create the state budget and control the dues collection. 
The volume and nature of the information about cash flows depends upon the method - direct or indirect of issuing of the statement of cash flows. The cash flow statement, issued by the indirect method, reflects the sources of the funds receipt and the funds employment within the period under review. Such information is necessary for the internal and external users of the accounting information as, while computing the data according to the principle of accumulation, the income and costs are computed only when they have been earned or encumbered, without taking into consideration the period of the funds receipt. Thus, the net profit, computed at the end of the period under review, does not reflect the increase of the amount of money, available in the company. The essence of the direct method of issuing and submission of the cash flow statement is as follows: while fixing the cash flows, the inflows and outflows from the company's operating activity within the period under review are computed. As a matter of fact, computation of cash flows by the direct and indirect methods differs. These differences are revealed while computing the cash flows from the company's operating activity. Computation of the cash flows from the financial, investment and extraordinary activity does not differ. The International Committee on the Standards of Accounting recommends to use the direct method for issuing of the cash flow statement.

According to the investigation, carried out by the Polish authors (Ignatowski et al 2002: 288) within the years 1990-1993 in 300 companies of Canada, 320 companies of Great Britain and 600 companies of the USA, the accounting on cash flows by applying the direct method is practiced by 1-2,5\% of the companies. A similar investigation was carried out by the authors of this article within the years 1994-2004 in the Lithuanian companies, involved in processing industry. The investigation proved that $93 \%$ of the companies apply the indirect method, whereas $7 \%$ apply the direct method. The indirect method is more popular because prior to the year 2003 the accounting on cash flows had to be issued only by applying this particular method according to the order, established by the Accounting laws.

The analysis of the EU Fourth Directive "Financial Statements of the Companies", which was carried out, proved that the Directive provides a sufficiently clear explanation how the balance, the profit (loss) statement should be issued, what kind of information the explanatory note should contain. However, no indications how to issue the cash flow statement are contained in the Directive. Thus, it would be worth to include the cash flow statement into the composition of financial accountability, regulated by the EU Fourth Directive. Such supplement to the Directive would be useful for the following reasons, i.e. 1) the average and large-scale companies practice complete financial accountability, including the cash flow statement; 2) certain misunderstandings would be avoided while filling in the cash flow statement; 3) the Directive would uniform the form of the cash flow statements in all the countries of the European Union.

The company's money is not only as the most mobile assets, but as the most appropriable assets as well. Thus, control of the inflows and outflows is very important. While dealing with the cash flow statement, while issuing the cash flow statement, the accountants (financiers) should devote the utmost attention towards assurance of the money and their equivalents safety control, towards the methods of the funds appropriation, towards revealing of the circumstances and towards blocking the way to the latter. The investigation, which was carried out, proved that the money thefts from the cash-desk, falsification of remuneration, etc. are the most frequent ways of the funds appropriation (please, see Fig 6). The picture reflects the most common cases of fictitious payments, i.e. the fictitious payments to the suppliers, the groundlessly paid remuneration, the money for the acquired goods or services, which has not entered the cash-desk in the shape of inflows or which has not entered the bank accounts; the rest of the money in the cash-desk is falsified by concealing the current shortage.

The following procedures should be applied, seeking to avoid mistakes and cases of fraud while computing the inflows and outflows, i.e. checking (checking of the documents and objects in kind), veracity, revealing, computation and recalculation, selection. While applying the checking procedure, checking of the documents and objects in kind is practiced. While carrying out checking of the goods in kind, the rest of the money and the tangible values in the company's cash-desk are checked as per each currency. While carrying out checking of the documents, the quality of the issued documents is evaluated, the proving documents, attached to the inflow and outflow orders, etc. are revised. While applying the checking procedure, it should be checked if all the obtained receivables have been registered and coordinated with the further bank procedures, if confirmation of the request introduced to the computer systems data is practiced, etc. While applying the revealing procedure, it should be checked, if the procedures of coordination with the bank are practiced, if coordination of the book-keeping accounts with the auxiliary books and the main 

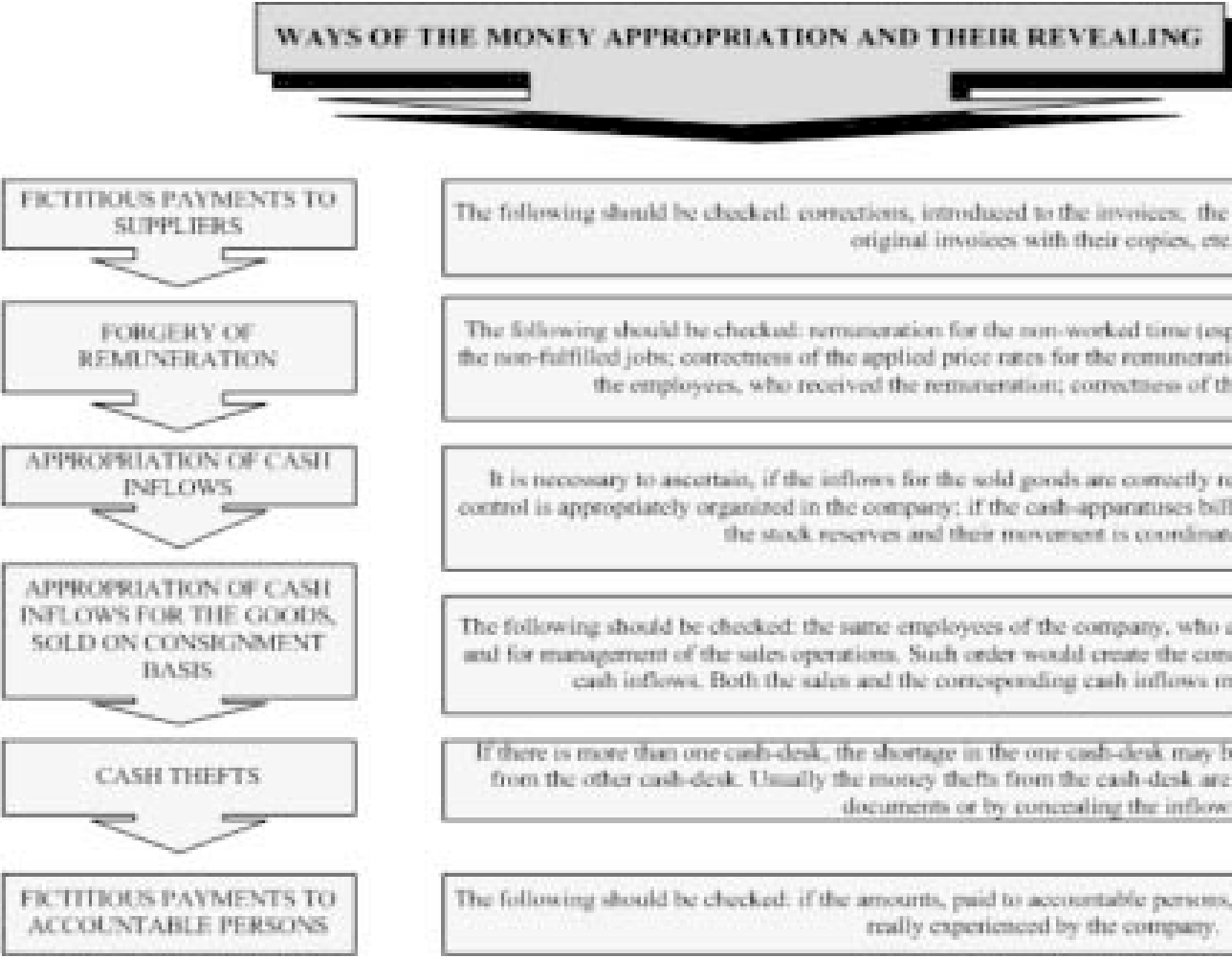

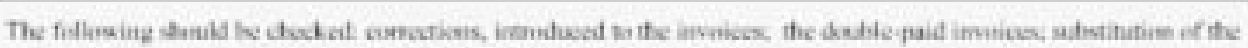
etigitinal imvices with their coppia, the

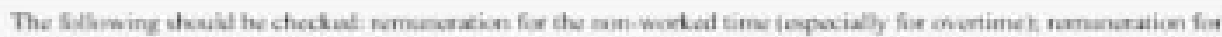

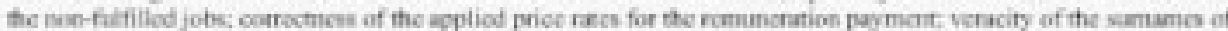

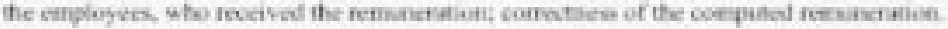

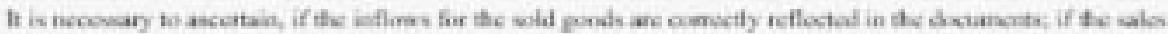

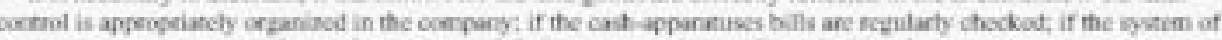

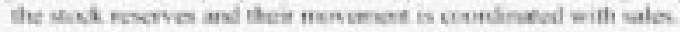

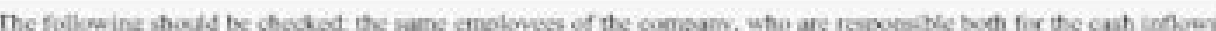

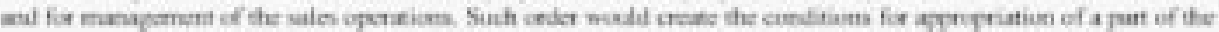

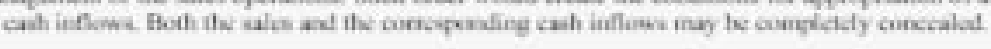

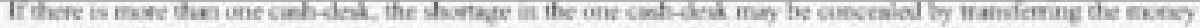

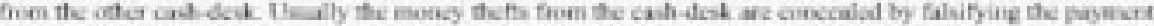
ducumers ex in cuncraling the inflom.

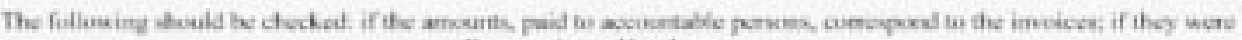
rally eapericteod by the courewry

Fig 6. The ways of the money appropriation and their revealing

registration lists is regularly practiced, if coding and checking of the operations (account correspondence) is practiced. While applying the computation and recalculation procedure, the actions on arithmetic addition, deduction, multiplication and division are practiced. While applying the selection procedure, only a part of the total information is selected and checked; usually it reflects monotype phenomena and operations. The interrogation can be streamed into the verbal and written interrogation. Application of the abovespecified procedures in the company helps to protect the funds from mistakes, appropriation and fraud.

\section{The analysis of cash flows}

In spite of the fact that the information about cash flows is very valuable both for the internal and the external information users, there is a large deficit of the literature, which could provide explanation which definite analytical methods should be used, how the conclusions about the obtained results should be drawn. Both the foreign and the Lithuanian authors analyze only the indices, reflected in the balance and profit (loss) statements. The authors, who had been attempting to analyze cash flows, mainly restricted themselves to computation of certain relative indices. However, computation of relative indices of cash flows is one of the elements of the methods of analysis of cash flows.
The studies of the Lithuanian and foreign authors' literature, published within the years 1994-2004, permit to draw the fundamental undeniable conclusion, i.e. no methods of analysis of cash flows have been prepared yet. The insufficient attention towards the analysis of cash flows can be explained by mentioning the following reasons, i.e. 1) most countries have started to issue the cash flow statements only since the years 1992-1994; 2) the authors' unwillingness to go deeper into frailties of issuing of the cash flow statement (wishing to analyze cash flows, it is necessary to be well aware of their accounting and methods of issuing of the statement; however, it is quite a complex matter). The analysis of cash flows should be carried out in a strict sequence.

The horizontal analysis allows to evaluate cash flows from the corresponding activity and their alterations within the passed periods under review; the inflows and outflows and their trends; they indicate the types of activity, which generate the largest cash flows. Later on this information can be used for preparation of the cash flow forecasts. The vertical analysis allows to ascertain parts of certain cash flows, generated by certain types of activity, in the general flow, to compare cash flows, generated by different types of the company's activity, in between themselves and to evaluate their alteration. This information can be used 
for forecasting of the corresponding alteration of the company's activity.

The problem of calculation and evaluation of financial ratios of cash flows is the most urgent. Various ratios of cash flows are suggested by the Lithuanian and foreign authors, whose works were dedicated to the items of financial analysis and accounting. Their variety of ratios is so vast that it becomes impossible to compare them. As the practice proves, the authors, who attempted to group the financial ratios of cash flows, attributed them differently to the groups of financial ratios (to solvency, profitability, the market of capital, efficiency of activities, etc.). The number of ratios and their names differ to a great extent; different terms are used for defining of one and the same ratio. Thus, it is more difficult to perceive the essence of cash flows and the methods of their calculation, their interpretation and translation. One and the same ratio, used in the works of Lithuanian authors is differently translated from the English, German or Russian languages into the Lithuanian language; thus, it is interpreted differently (Mackevičius et al 1998: 106). Moreover, attention should be drawn to the fact that the foreign authors offer the methods of calculation of ratios, based on financial statements of their countries. As the name and content of ratios of the financial statements of certain countries differ, so the ratios themselves are calculated differently by the authors of different countries. For example, G. I. White, C. Ashwinpaul, D. F. Sondhi (1997: 768) suggest to calculate the ratios of coverage of interests, of coverage of the fixed assets, of the rate of the capital costs, of correlation of the net cash flows out of operations and of all the debts; P. Stickney (1999: 492) operating cash flow to current liabilities ratio, operating cash flow to cash interest cost ratio, operating cash flow to total liabilities ratio, operating cash flow to capital expenditures ratio, etc. The Russian author N. V. Volobina (2000: 29) singles out even 18 ratios, however a part of the financial ratios of cash flows, offered by her, are less significant; it is difficult to judge about the impact, which they produce upon the concrete sphere of activity from their size. The same pertains to the other authors. On the other hand, calculation of the other ratios is too complex; so as to calculate them, it is necessary to search for the information from the registers of synthetic and analytical accounting.

The variety of calculation of financial ratios of cash flows can be justified by the following reasons:

1) the financial statements as well as the names of their articles differ in various countries;

2) the authors use the terms of such branches of activity, which have been investigated;
3) some Lithuanian authors automatically translate a certain ratio into the Lithuanian language, without going deeper into the methods of its calculation.

However, it is less important to state that the authors specify different financial ratios of cash flows, than to state that they do not calculate and analyze them at all. Even the newest books of the authors (Black 2004: 207-219; Jiambalvo 2004: 467-478; Weygand et al 2005: 710-755) allocate too little attention to analyzing of cash flows; usually only examples of inflows and outflows are presented and, in the best case, their horizontal and vertical analysis. It is necessary to calculate and analyze cash flows as well as the relative sizes of the other financial ratios so as to take the correct business solutions.

While calculating the financial ratios of cash flows, the operating attention should be devoted to the cash flows from operating activities (Mackevičius et al 1997: 245). This is motivated by the fact that most of the inflows come from the operating activity (inflows from the clients) and these inflows are the most constant and received each month, decade, week and day, whereas the inflows out of the investment and financial activities are seldom and single (for example, return of the loans, acquisition of the loans, the owners' contributions, etc.). Thus, while calculating various financial ratios, it is expedient to use the cash flows out of the operating activity or the ratio of increase (decrease) of the net cash flows, which evaluates alterations, which take place in all spheres of the company's activity, i.e. the cash flows from operating, investment and financial activities.

Cash flows produce the largest influence upon the company's solvency and profitability, i.e. upon the ratios, which stipulate efficiency and continuity of the company's activities. Thus, it is necessary to calculate and analyze such financial ratios of cash flows, which produce the largest impact upon efficiency of the company's activities. It is suggested to single out three groups of financial ratios of cash flows, i.e.:

1) the ratios of cash flows, related with the company's profitability;

2) the ratios of cash flows, related with the company's solvency;

3) the other ratios of cash flows.

The financial ratios of cash flows, which are suggested to be calculated, are revealed in Fig 7 .

All information (related with forecasting of cash flows), which is necessary for the further stages of forecasting, is accumulated at the first stage of the information accumulation. This information includes the follow- 


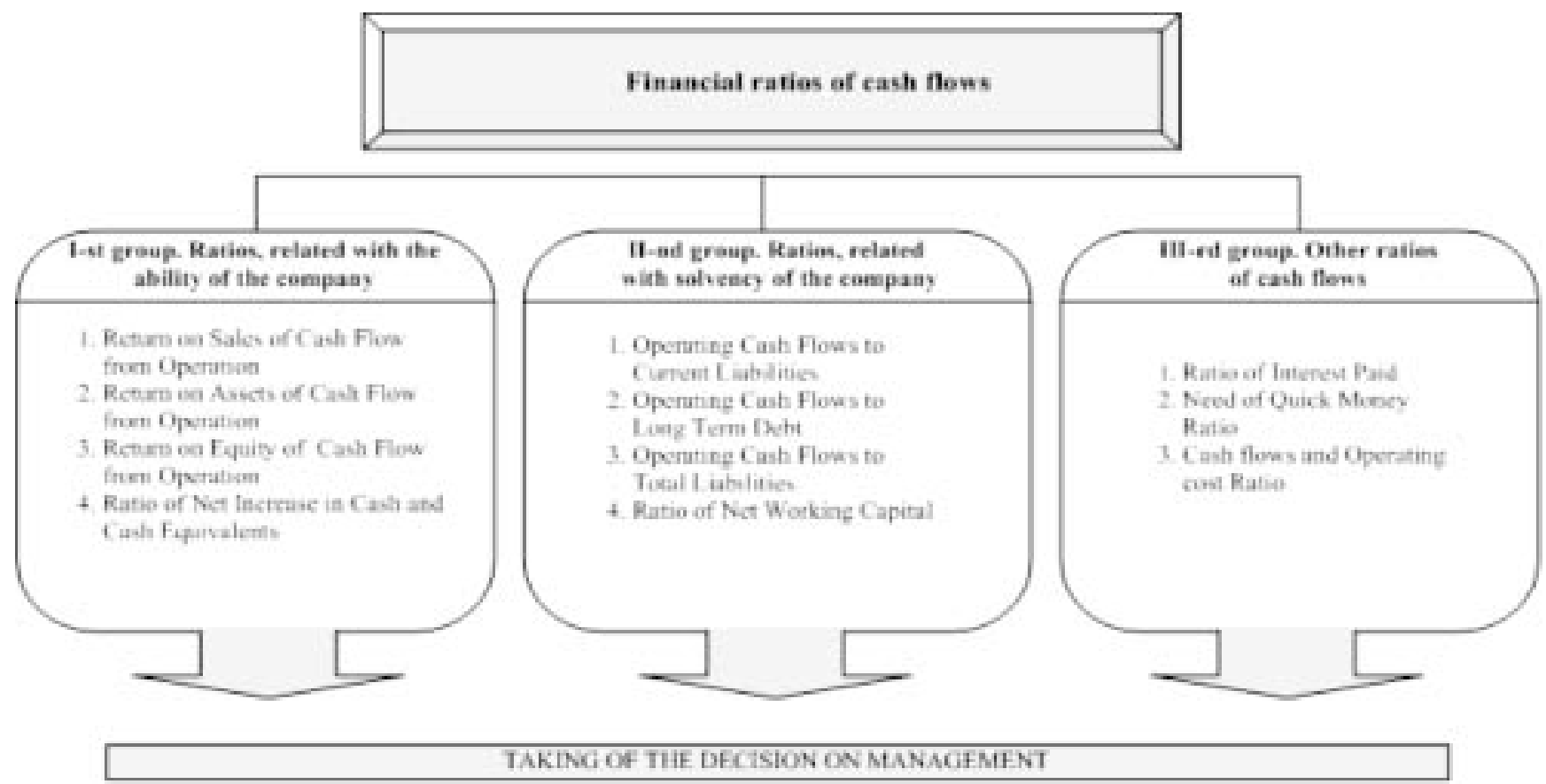

Fig 7. Financial ratios of cash flows

ing information, i.e. the company's position at the market, the manufactured products' prime-cost and the sale income, the competitors' position at the market, etc. The income and costs are forecasted at the second and third stages with taking into consideration the accumulated information. The profit is forecasted at the fourth stage. Seeking to forecast the company's cash flows, the income and costs should be converted into the inflows and outflows. The stage of evaluation and ascertainment of cash flows is the final stage of forecasting. This stage implies computation of the net cash flow after forecasting. The factors, which predetermine the choice of the method (direct or indirect) of the forecasted cash flow statement, are as follows: the level of detailing and precision of the forecast; the forecasted term; the form of the information submission, requested by the information user; the need to issue not only the cash flow forecast, but the forecast of indices, reflected in the other statements as well; working experience and qualification of the expert, who prepares the forecast. While analyzing the aspects of the above-specified factors, which predetermine the choice of the form of the direct and indirect cash flow statement, both advantages of the direct and indirect methods of forecasting are singled out. Referring to the advantages of one or another method of the statement, however, ignoring influence of the subjective factors, which predetermine the choice of the statement (the forecaster's experience, opinion about selection of the form and the information user's request, concerning the form of the statement), it was ascertained that: 1) it is necessary to maximize the level of precision and detailing of the forecast as well as to reduce the time intervals for forecasting within the year of the forecasted period, when there is a large risk of liquidity (shortage of funds). Thus, cash flows should be forecasted by the direct method and within the sufficiently short time intervals (quarterly or monthly); 2) the optimal level of the forecast precision and detailing should be kept within the whole forecasted period. Thus, cash flows should be forecasted by the indirect method and within no longer than one-year interval.

\section{Conclusions}

It is worth to classify the company's cash flows according to the types of the company's activity and the time duration. The cash flow classification according to the types of the company's activity provides the information, which provides the users with the possibility to evaluate the influence of this activity upon the company's financial condition, upon the amount of money and its equivalents as well as to evaluate relations in between the types of activity. According to the types of the company's activity, cash flows are streamed into the cash flows from the company's operating, financial and investment 
activities. The investigation proved that the cash flows from the operating activity of the companies, attributed to the processing industry of Lithuania, make the largest comparative part of cash flows (67\%), from the financial activity $-16 \%$ and from the investment activity $-17 \%$. The cash flows according to the time duration are streamed into the short-term and long-term cash flows. The short-term cash flows mainly depend upon the company's activity cycle. Formation of the information about the long-term cash flows implies fixing of the company's demand for external financing and the investment decisions.

While investigating the items of the cash flow accounting, the reasons, which caused the delay of introduction of the cash flow statement were revealed, i.e. 1) confidentiality - the companies never wish to announce the detailed information about the condition of their funds and the sources of their receipt and employment; 2) resistance to novelties - the cash flow statement is the most complicated among the existing statements. Accountants were not interested in spending the time on issuing the new statements and on going deeper into the frailties of their issuing; 3) issuing of the statement as per the money principle - the experts of the accounting used to stress constantly the drawbacks of accounting, managed according to the principle of money accounting, and used to raise importance of accounting, managed according to the principle of accumulation.

After having carried out the investigation in the companies, attributed to the processing industry of Lithuania, within the years 1994-2004, it was revealed that $93 \%$ of the companies had been applying the indirect method, of issuing of the cash flow statement whereas $7 \%$ of them had been applying the direct method. The indirect method is more popular because prior to the year 2003 the cash flow statement had to be issued only by applying this particular method in accordance with the procedure, established by the laws.

The analysis of the EU Fourth Directive "Financial Statements of the Companies", which was carried out, proved that the Directive provides a sufficiently clear explanation how the balance, the profit (loss) statement should be issued, what kind of information the explanatory note should contain. However, no indications how to issue the cash flow statement are contained in the Directive. Thus, it would be worth to include the cash flow statement into the composition of financial accountability, regulated by the EU Fourth Directive. Such supplement to the
Directive would be useful for the following reasons, i.e. 1) the average and large-scale companies practice complete financial accountability, including the cash flow statement; 2) certain misunderstandings would be avoided while filling in the cash flow statement; 3 ) the Directive would uniform the form of the cash flow statements in all the countries of the European Union.

The reasons, which predetermined the insufficient attention, drawn towards the cash flow analysis, were singled out, i.e. 1) most countries have started to issue the cash flow statements only since the years 19921994; 2) the authors' unwillingness to go deeper into frailties of issuing of the cash flow statement (wishing to analyze cash flows, it is necessary to be well aware of their accounting and methods of issuing of the statement; however, it is quite a complex matter).

The reasons, which predetermine variety of computation of the financial ratios of cash flows, were ascertained, i.e. 1) various countries practice different titles of the financial statement and the articles, specified in them; 2) the authors apply the terms, pertaining to the branches of activity, in which the investigations had been carried out; 3) certain Lithuanian authors automatically translate certain indices into the Lithuanian language, without going deeper into the methods of their computation; 4) some terms in the English language have no compliance in the Lithuanian language. It is suggested to single out three groups of financial ratios of cash flows, i.e.: 1) the ratios of cash flows, related to the company's profitability; 2) the ratios of cash flows, related to the company's solvency; 3 ) the other ratios of cash flows.

\section{References}

Black, G. (2004) Applied Financial Accounting and Reporting. London: Oxford University Press. 596 p.

International Financial Reporting Standards (2004). London: IASCF. $781 \mathrm{p}$.

Jiambalvo, J. (2004) Managerial Accounting. Second Edition. John Wiley \& Sons, Inc. 459 p.

Mackevičius, J.; Poškaitè, D. (1998) Finansinè analizė (Financial Analysis). Vilnius: Katalikų pasaulis. 631 p.

Mackevičius, J.; Poškaitè, D. (1997) Finansinès ataskaitos (Financial Statements). Vilnius: Katalikų pasaulis. 351 p.

Mayer, T.; Duesenberry, J. S.; Aliber, R. Z. (1995) Pinigai, bankai ir ekonomika (Money, banks and economics). Vilnius: Alma littera. 639 p.

Międzynarodowe regulacje rachunkowošci (International reguliation of accounting). Ignatowski, R.; Jaruga, A.; 
Kabalski, P. etc. (2002) Warszawa, Wydawnictwo: C. H. Beck. 372 p.

On annual financial accounting of the companies, provided with the legal person's rights. Resolution No 804, adopted by the Government of the Republic of Lithuania on 1993 October 27. No 58.

Pass, Ch.; Lowes, B.; Davies, L. (1997) Ekonomikos terminu žodynas (Dictionary of Accounting Terms). Vilnius: Baltijos biznis. 183 p.

Stickney, C. P.; Brovvn, P. R. (1999) Financial reporting and statement analysis. Orlando: Harcourt, Inc. 964 p.

Verslo apskaitos standartai (National accounting standards) (2004) Vilnius: Mūsų saulužè. 183 p.
White, Gerald I.; Sondhi, Ashwinpaul C.; Fried, D. (1997) The Analysis and Use of Financial Statements. Second Edition. New York: John Wiley \& Sons, Inc. 679 p.

Weygand, J. J.; Kieso, D. E.; Kimmel, P. D. (2005) Accounting Principles. Seventh Editon. John Wiley \& Sons, Inc. $538 \mathrm{p}$.

Волобина, Н. В. (2000) Анализ движения денежных средств (Analysis of Cash Flows). Бухгалтерский учет 21: 74-79. 